\title{
Peningkatan Kemampuan Sosial Masyarakat dan Komitmen Politik Kepala Daerah dalam Pengentasan Permukiman Kumuh di Kabupaten Cirebon
}

\author{
Dede Setiawan, \\ Gili Argenti, \\ Moch Faizal Riski \\ Universitas Singaperbangsa Karawang \\ J1. HS. Ronggo waluyo, Puseurjaya, Kecamatan telukjambe Timur, \\ Kabupaten Karawang, Jawa Barat 41361 \\ 1610631180033@student.unsika.ac.id
}

Received: 05th November 2020; Revised: 09th March 2021;

Accepted: 09th March 2021

\begin{abstract}
Slum settlements are a very complex problem because they contain several indicators that are very important to be addressed, including buildings, environmental roads, drinking water supply, environmental drainage, waste water management, solid waste management, fire protection and public open spaces. This article aims to determine the factors for increasing the social capacity of the community and how the commitment of the regional head in dealing with slum settlements in Cirebon Regency. How the community plays an active role in the programs that have been implemented by the Government and the commitment of the Cirebon Regency government to address the problem of slum settlements. This research is a qualitative research using descriptive analysis method. This study uses the object of interviews with informants as an object of information that aims to achieve goals in order to obtain information in research. The formulation of the problem in this article the writer uses the concept of political commitment according to Brinkerhoff (2010) which consists of government initiatives, priorities, mobilization of political support, law enforcement, and business sustainability. Based on the results of the study, it can be concluded that the social capacity of the community is still lacking and the political commitment of the regional head still has obstacles in the priority dimension due to the limited budget and the absence of a legal umbrella such as the PERDA in alleviating slums in Cirebon Regency.
\end{abstract}

Keywords: slum settlements; social ability; political commitment; cirebon regency

\section{ABSTRAK}

Permukiman kumuh merupakan masalah yang sangat kompleks karena didalamnya terdapat beberapa indikator yang sangat penting untuk ditangani antara lain adalah bangunan gedung, jalan lingkungan, penyediaan air minum, drainase lingkungan, pengelolaan air limbah, pengelolaan persampahan, protrkesi kebaran dan ruang terbuka publik. Artikel ini bertujuan untuk mengetahui faktor-faktor peningkatan kemampuan sosial masyarakat dan bagaimana komitmen kepala daerah dalam menangani permukiman kumuh di Kabupaten Cirebon. Bagaimana masyarakat berperan aktif 
terhadap program yang sudah dilaksanakan oleh Pemerintah serta komitmen pemerintah Kabupaten Cirebon untuk mengatasi permasalahan permukiman kumuh. penelitian ini merupakan penelitian kualitatif dengan menggunakan metode analisis deskriptif. Penelitian ini menggunakan objek wawancara dengan informan sebagai objek informasi yang bertujuan untuk mencapai tujuan guna memperoleh informasi dalam penelitian. Rumusan masalah dalam artikel ini penulis menggunakan konsep Komitmen politik menurut Brinkerhoff (2010) yang terdiri dari inisiatif pemerintah, prioritas, mobilisasi dukungan politik, penegakan hukum, dan keberlanjutan usaha. Berdasarkan hasil penelitian dapat disimpulkan bahwa kemampuan sosial masyarakat masih kurang dan komitmen politik dari kepala daerah masih terdapat kendala dalam dimensi prioritas karena anggaran yang terbatas dan belum adanya paying hukum seperti PERDA dalam pengentasan permukiman kumuh di Kabupaten Cirebon.

Kata Kunci: permukiman kumuh; kemampuan sosial; komitmen politik; kabupaten cirebon

\section{PENDAHULUAN}

Permukiman kumuh merupakan fenomena global, di banyak negara berkembang masalah ini menjadi semakin parah karena berkaitan dengan tingginya pertumbuhan penduduk dan tingkat kemiskinan meningkat. Penyebab lainnya adalah tidak meratanya pembangunan sehingga lapangan pekerjaan yang hanya tersedia di wilayah perkotaan menjadikan daya tarik bagi penduduk dari perdesaan untuk bermigrasi ke kota. Migrasi penduduk dari desa ke kota ini menimbulkan ekses negatif lainnya seperti populasi yang padat, pengangguran, tata kota yang semrawut, kriminalitas, konflik sosial dan kerusakan lingkungan. Fenomena permukiman kumuh banyak terjadi di berbagai belahan dunia, khususnya di negara berkembang. Pada tahun 2012, sekitar 863 juta orang di negara berkembang tinggal di daerah kumuh. Dari jumlah tersebut, populasi daerah kumuh perkotaan pada pertengahan tahun adalah sekitar 213 juta di Afrika Sub-Sahara, 207 juta di Asia Timur, 201 juta di Asia Selatan, 113 juta di Amerika Latin dan Karibia, 80 juta di Asia Tenggara , 36 juta di Asia Barat, dan 13 juta di Afrika Utara (Un Habitat, 2013).

Pemukiman kumuh selalu ditandai dengan terlalu banyaknya penduduk yang tinggal di suatu wilayah tanpa memperhatikan esensi kelayakan huni. Kelayakan huni dapat diukur dengan adanya indikator: akses terhadap kebutuhan dasar yang cukup, sanitasi yang memadai, ketersediaan air bersih, ketahanan bangunan, ruang hidup yang memadai, serta jaminan layak huni (Prayitno, 2007). Pemukiman kumuh seringkali didefinisikan sebagai pemukiman tidak formal yang ditandai dengan : (1) Status hunian yang tidak aman, (2) Sulitnya akan akses air bersih, (3) akses yang tidak memadai terhadap sanitasi, infrastruktur, dan layanan publik lainnya, (4) Kualitas perumahan yang tak layak/buruk, (5) Terjadi kepadatan yang berlebihan (Un-Habitat, 2007). Upaya untuk mencoba mengurangi dan mengubah daerah kumuh di berbagai negara sudah banyak dilakukan dengan berbagai tingkat keberhasilan, termasuk kombinasi pemindahan daerah kumuh, peningkatan daerah kumuh, perencanaan kota dengan pembangunan infrastruktur di seluruh kota, dan perumahan publik (Un-Habitat, 2007). Selama dua dekade terakhir, beberapa negara yang membuat kemajuan signifikan dalam perjuangan melawan pertumbuhan permukiman kumuh adalah tempat di mana dukungan politik tersebar luas untuk mengurangi prevalensi daerah kumuh dan di mana Political Will yang tulus diungkapkan untuk mengekang daerah kumuh ekspansi misalnya, di Mesir dan Meksiko (Un Habitat, 2013). 
Undang-undang No. 1 Tahun 2011 tentang Perumahan dan Kawasan Permukiman menjelaskan bahwa kawasan permukiman adalah bagian dari lingkungan hidup di luar kawasan lindung, baik berupa kawasan perkotaan maupun perdesaan, yang berfungsi sebagai lingkungan tempat tinggal atau lingkungan hunian dan tempat kegiatan yang mendukung perikehidupan dan penghidupan. Selanjutnya dijelaskan pula permukiman kumuh adalah permukiman yang tidak layak huni karena ketidakteraturan bangunan, tingkat kepadatan bangunan yang tinggi, dan kualitas bangunan serta sarana dan prasarana yang tidak memenuhi syarat. Seperti yang dikemukakan dalam kerangka kerja pengelolaan lingkungan dan sosial Kementerian Pekerjaan Umum dan Perumahan Rakyat, terdapat sekitar 22\% penduduk perkotaan di Indonesia yang bermukim di wilayah permukiman kumuh dimana akses terhadap pelayanan dasar minimumnya masih rendah. Kriteria kumuh tersebut ditandai dengan perumahan-perumahan yang masih dibawah standar, masih belum terpenuhinya akses infrastruktur dasar (air, sanitasi, jalan, dll), kesehatan lingkungan yang buruk serta kawasan rumah yang kondisinya berdesak-desakan dan rentan akan bencana alam.

Menurut Data Warehouse Direktorat Cipta Karya tahun 2017 di Indonesia kawasan permukiman kumuh masih terbilang tinggi yaitu 42.470,55 hektar khususnya di Provinsi Jawa Barat pada tahun 2017, permukiman kumuh mencapai 3.321,98 hektare dan mengalami kenaikan pada tahun 2018 menjadi 4.148,57 hektare yang tersebar di 27 Kabupaten dan Kota. Termasuk di dalamnya Kabupaten Cirebon, dari tahun 2015 sampai saat ini masih banyak terdapat kawasan permukiman kumuh di Kabupaten Cirebon. Terdapat 195 desa dan kelurahan yang termasuk kedalam kawasan kumuh dan dari jumlah tersebut hanya beberapa kawasan yang mendapatkan program pengentasan permukiman kumuh.

Permasalahan permukiman kumuh muncul karena rendahnya minat para pemangku kepentingan untuk melakukan pentingnya kebijakan publik dalam perumahan yang mendukung bagi masyarakat miskin karena dampak jangka panjangnya akan berdampak pada kesehatan, kehidupan keluarga dan pada akhirnya dapat memicu kejahatan, pendidikan terbatas, pendapatan dan pekerjaan (Hartman, 1998). Pengentasan kawasan kumuh juga harus disertai dengan kemauan politik (Political will) para pemangku kebijakan. Diskusi antar pelaku menjadi solusi agar saling menguatkan dan menemukan solusi tepat dengan melibatkan berbagai aktor. Salah satu contoh konkret implementasi political will adalah keseriusan pemerintah dalam mempromosikan pengentasan permukiman kumuh sebagai agenda Prioritas kebijakan nasional. Saat ini political will masih dianggap lemah yang terbukti dari capaian kinerja terhadap pengentasan kawasan kumuh yang cenderung lebih meningkat. Selain itu permasalan kawasan kumuh terletak pada aksi pemerintah yang belum mampu menjajarkan dengan pemenuhan kebutuhan hak dasar lainnya seperti pangan, pendidikan, kesehatan, dan lapangan kerja. Hal ini dapat dilihat dari kebijakan sistem jaminan sosial nasional (SJSN) yang arahnya berkontribusi terhadap Rencana Pembangunan Jangka Panjang Nasional (RPJMN) Tahun 2005-2025. Aspek komitmen politik atau Political will tidak terlepas dari sistem tata kelola (Governance) penanganan kawasan kumuh. Orientasi pelaksanaan dan implementasi terhadap permasalahan kekumuhan yang selama ini lebih banyak ke arah rule based harus dipadukan dengan outcome based. Langkah ini sebagai 
pemecahan permasalahan ketidaktepatan sasaran dan masih terlalu rigidnya kebijakan sehingga justru tidak menyelesaikan permasalahan kawasan kumuh dan bahkan cenderung menjadi boomerang dalam pelaksanaanya (Prayitno, 2007).

Berdasarkan data kawasan permukiman kumuh Dinas Perumahan Kawasan Permukiman dan Pertanahan (DPKPP) dapat diketahui bahwa di Kabupaten Cirebon di tahun 2019 kawasan permukiman kumuh masih cukup tinggi. Dari keseluruhan kawasan permukiman kumuh, Indikator permasalahan permukiman kumuh yang paling banyak di Kabupaten Cirebon meliputi bangunan gedung, jalan lingkungan, penyediaan air minum, drainase lingkungan, pengelolaan air limbah, pengelolaan persampahan, proteksi kebakaran + rtp yang kurang layak, seperti di desa Ambulu yang memiliki kawasan kumuh paling besar di Kabupaten Cirebon, bahkan desa Ambulu termasuk kedalam kategori desa sangat tertinggal. Mendapatkan permukiman yang layak adalah hak setiap warga.

Di Kabupaten Cirebon dalam menangani permukiman kumuh sudah berjalan dari tahun 2017 melalui program KOTAKU akan tetapi Program yang dilakukan oleh pemerintah Kabupaten Cirebon tidak seluruhnya mencakup kawasan permukiman kumuh yang ada sehingga menyebabkan tekanan publik yang menginginkan untuk pemerintah lebih serius dalam menangani permukiman kumuh. Penanganan kawasan permukiman kumuh yang ada di Kabupaten Cirebon melalui program KOTAKU dari 195 kawasan permukiman kumuh baru 11 kawasan yang berada di 10 Desa ditangani. Dari 11 kawasan tersebut Pemerintah Kabupaten Cirebon melalui Dinas Perumahan Kawasan Permukiman dan Pertanahan (DPKPP) memprioritaskan pembangunan untuk dibenahi menurut 7 Indikator permukiman kumuh yaitu pengembangan perumahan, jaringan jalan lingkungan, jaringan drainase, jaringan air minum, persampahan, dan air limbah, serta lainnya.

Program KOTAKU merupakan program yang berbasis pemberdayaan masyarakat oleh karenanya peranan masyarakat dalam pengentasan permukiman kumuh sangat penting oleh sebab itu tidak hanya pemerintah saja yang harus mempunyai komitmen akan tetapi masyaralat juga diharapkan memiliki tanggung jawab yang sama. Di Kabupaten Cirebon pasrtisipasi masyarakat yang diberikan dalam program pengentasan permukiman kumuh secara keseluruhan masih kurang. Hal tersebut menjadi tantangan bagi Pemerintah untuk bisa meningkatkan peran aktif masyarakat dalam proses pengentasan masalah permukiman kumuh. Peningkatan kemampuan masyarakat dapat dilakukan dengan pemberian komitmen masyarakat, terlibat aktif dalam pengambilan keputusan, perencanaan, implementasi, pemeliharaan, pengawasan dan kontribusi peningkatan kualitas sosial ekonomi pada penataan kawasan kumuh prioritas. Peningkatan kapasitas governansi pemerintah dapat dilakukan dengan mendorong Pimpinan Daerah, memberikan komitmen politik untuk menetapkan penanganan program Prioritas dalam penanganan kawasan permukiman kumuh (Heston A, 2013).

Komitmen politik Bupati Cirebon dalam menangani permukiman kumuh melalui inisiatif pembuatan program-program yang berkaitan dengan indikator permukiman kumuh sudah tercantum dalam visi misi Bupati dan RPJMD Kabupaten Cirebon. Komitmen politik yang diperlukan bukan melakukan pengentasan permukiman kumuh sekedar untuk mengeruk keuntungan 
material, akan tetapi yang dikehendaki adalah benar-benar merupakan niat dan tekad yang tulus untuk menangani permukiman kumuh besrta isinya tanpa reserve atau pamrih. Komitmen politik ini amat penting, lebih-lebih di tengah perhatian terhadap upaya peningkatan kualitas hidup masyarakat agar kehidupan masyarakat lebih sejahtera.

Berdasarkan uraian diatas penelitian ini diarahkan untuk mengetahui faktor-faktor yang dapat meningkatkan kemampuan sosial masyarakat dan mengetahui bagaimana Komitmen Politik Pemerintah Kabupaten Cirebon dalam menangani permukiman kumuh. selanjutnya yang menjadi acuan dalam analisis dalam penelitian ini adalah Teori Political will atau komitmen politik menurut Brinkerhoff (2010) yang memiliki 5 dimensi yaitu : inisiatif pemerintah, prioritas, mobilisasi dukungan politik, penegakan hukum dan keberlanjutan usaha.

\section{METODE PENELITIAN}

Penelitian ini merupakan penelitian kualitatif dengan menggunakan metode deskriptif.Subjek dalam penelitian ini ialah instansi pemerintah yang bertanggung jawab yakni Bupati Kabupaten Cirebon melalui instansi terkait Permukiman Kumuh yaitu Dinas Perumahan, Kawasan Permukiman dan Pertanahan (DPKPP), Sekertariat Program KOTAKU, Komisi III DPRD Kabupaten Cirebon dan juga Masyarakat Kawasan permukiman kumuh di Desa Ambulu dan Desa Belawa. Informan dalam penelitian ini menggunakan teknik purposive sampling, yaitu cara penentuan informan yang ditetapkan secara sengaja atas dasar kriteria atau pertimbangan tertentu.

Teknik analisis data dalam penelitian kualitatif menurut John W Creswell (Creswell, 2016) akan berlangsung bersamaan dengan bagian-bagian lain dari pengembangan penelitian, yaitu pengumpulan data dan penulisan temuan. Ketika wawancara sedang berlangsung misalnya peneliti dapat menganalisis wawancara yang dikumpulkan sebelumnya, menuliskan memo yang pada akhirnya dituliskan dalam laporan akhir. Karena tidak semua data dapat digunakan dalam penelitian maka, peneliti dapat memisahkan data serta memfokuskan pada sebagian data dan meninggalkan bagian-bagian lainnya. Penelitian ini dilakukan untuk mendapat gambaran secara utuh tentang Faktorfaktor yang mempengaruhi kemampuan peningkatan sosial dalam menangani permukiman kumuh dan komitmen politik atau Political will Pemerintah Kabupaten Cirebon dalam menanggulangi permukiman kumuh. Proses analisis dimulai dengan menelaah seluruh data yang tersedia dari berbagai sumber baik dari hasil studi pustaka maupun studi lapagan.

\section{HASIL DAN PEMBAHASAN}

Permukiman kumuh adalah permukiman yang tidak layak huni karena ketidakaturan bangunan, tingkat kepadatan bangunan yang tinggi, dan kualitas bangunan serta sarana dan prasana yang tidak memenuhi syarat. Indikator kawasan permukiman kumuh yang menjadi acuan bagi pemerintah dalam menentukan tingkat kekumuhan suatu wilayah antara lain, yaitu bangunan gedung, jalan lingkungan, penyediaan air minum, drainase lingkungan, pengelolaan air limbah, pengelolaan persampahan, protrkesi kebaran dan Ruang Terbuka Publik (Pedoman umum KOTAKU, 2016). 
Menurut data Dinas Perumahan Kawasan Permukiman dan Pertanahan (DPKPP) Kabupaten Cirebon, kawasan permukiman kumuh di Kabupaten Cirebon persebarannya dibagi menjadi tiga yaitu zona barat, zona tengah, dan zona timur. Kemudian permukian kumh dikelompokan menjadi kawasan permukiman kumuh tinggi, kawasan permukiman kumuh sedang, kawasan permukiman kumuh rendah, dan kawasan permukiman tidak kumuh sesuai dengan 7 Indikator kumuh dan dalam perhitungannya menggunakan R0, R0 merupakan sistem perhitungan statisik dari pemerintah pusat. Dalam penanganannya terdapat dua bentuk yaitu peningkatan dan pencegahan. Peningkatan ditujukan untuk kawasan permukiman yang termasuk kedalam kawasan permukiman kumuh sedang dan tinggi. Sementara bentuk pencegahan ditujukan untuk kawasan permukiman yang masih kumuh rendah.

Berikut merupakan data kawasan permukiman kumuh di Kabupaten Cirebon menurut data Dinas Perumahan Kawasan Permukiman dan Pertanahan (DPKPP) tahun 2019.

Tabel 2.1 Data Permukiman Kumuh Kabupaten Cirebon

\begin{tabular}{ll}
\hline Jumlah Desa dan Kelurahan & 424 Desa dan Kelurahan \\
\hline Jumlah desa yang termasuk kumuh & 195 Desa \\
\hline Jumlah kategori peningkatan & 10 Desa \\
\hline Jumlah kategori pencegahan & 125 Desa \\
\hline \multicolumn{2}{c}{ Sumber : Dinas Perumahan Kawasan Permukiman dan Pertanahan, 2019 }
\end{tabular}

Dari data diatas dapat diketahui bahwa di Kabupaten Cirebon ada 195 Desa yang termasuk kedalam kumuh dan 125 Desa dalam kategori pencegahan serta ada 10 Desa yang menjadi kategori peningkatan. Di dalam SK Bupati Cirebon tentang penetapan lokasi perumahan dan permukiman kumuh tahun 2014 terdapat 10 desa yang merupakan kawasan prioritas Pemerintah Daerah Kabupaten Cirebon yang masuk kedalam kriteria Program KOTAKU (Kota Tanpa Kawasan Kumuh).

Berikut merupakan daftar kawasan permukiman kumuh Kabupaten Cirebon yang termasuk dalam kategori peningkatan, ada 11 Kawasan permukiman kumuh yang berada di 10 desa / kecamatan. 
Tabel 2.2 Kawasan Permukiman Kumuh Kategori Peningkatan

\begin{tabular}{llllll}
\hline No & Kecamatan & \multicolumn{1}{c}{ Desa } & \multicolumn{1}{c}{ Kawasan Kumuh } & $\begin{array}{c}\text { Luas } \\
\text { (Ha) }\end{array}$ & $\begin{array}{c}\text { Jumla } \\
\mathbf{h ~ K k}\end{array}$ \\
& & & & & \\
\hline $\mathbf{1}$ & Sumber & Sumber & $\begin{array}{l}\text { Blok Wage - Karang Anyar } \\
\text { (RW.03 dan 10) }\end{array}$ & 7,19 & 417 \\
\hline $\mathbf{2}$ & Weru & Situ Kulon & Blok Curug (RW.01) & 6.83 & 367 \\
\hline $\mathbf{3}$ & Palimanan & Semplo & Blok Pondok Bata (RW.05) & 1.97 & 152 \\
\hline $\mathbf{4}$ & Arjawinangun & Junjang & Blok I (RW.02) & 5.08 & 209 \\
\hline $\mathbf{5}$ & Ciledug & Jatiseeng & $\begin{array}{l}\text { Dusun Pahing - Wage } \\
\text { (RW.02, 04 dan 05) }\end{array}$ & 14,25 & 707 \\
\hline $\mathbf{6}$ & Plumbon & Danamulya & Blok Soka Lor (RW.02) & 3.84 & 317 \\
\hline $\mathbf{7}$ & Gunung Jati & Astana & RW.04 & 4.72 & 380 \\
\hline $\mathbf{8}$ & Losari & Ambulu & $\begin{array}{l}\text { Dusun Manis - Pahing } \\
\text { (RW.02, 03 dan 04) }\end{array}$ & 19,11 & 925 \\
\hline $\mathbf{9}$ & Astanajapura & Kanci Kulon & RW.03 - 04 & 5,62 & 573 \\
\hline $\mathbf{1 0}$ & Lemahabang & Belawa & Blok D (RW.05 \& 06) & 10.17 & 319 \\
\hline Jumlah $\quad \mathbf{1 0}$ KEC. & $\mathbf{1 0}$ DESA & $\mathbf{1 1 ~ K A W A S A N}$ & $\mathbf{7 8 . 7 8}$ & $\mathbf{4 . 3 6 6}$ \\
\hline
\end{tabular}

Sumber : Selayang Pandang DPKPP, 2019

Dari data diatas dapat diketahui bahwa di Kabupaten Cirebon kawasan permukiman kumuh yang masuk dalam kategori peningkatan secara keseluruhan luasnya 78,78 Hektar yang tersebar di 11 kawasan dan 10 Desa/Kecamatan. Unutk kawasan yang memiliki tingkat kekumuhannya paling tinggi berada di Desa Ambulu Kecamatan Losari yang juga merupakan kawasan prioritas permukiman kumuh. Setiap kawasan memiliki karakteristik masalah permukiman kumuh yang menjadi prioritas untuk dibenahi menurut 7 Indikator permukiman kumuh.

Berikut ini merupakan data prioritas permukiman kumuh di Kabupaten Cirebon menurut SK Bupati Kabupaten Cirebon tentang daftar lokasi perumahan dan permukiman kumuh : 


\section{Tabel 2.3 Lokasi dan Prioritas Pembangunan Perumahan Kumuh dan Permukiman Kumuh Kabupaten Cirebon}

\begin{tabular}{|c|c|c|}
\hline No & Nama Lokasi & Prioritas \\
\hline 1. & $\begin{array}{l}\text { Kawasan Blok Wage, Rw. } 03 \\
\text { Kelurahan Sumber Kecamatan } \\
\text { Sumber }\end{array}$ & $\begin{array}{l}\text { Peningkatan jalan, perbaikan rumah tidak } \\
\text { layak huni, pengadaan air minum/baku, } \\
\text { pembuatan dan perbaikan saluran drainase, } \\
\text { pengelolaan sampah }\end{array}$ \\
\hline 2. & $\begin{array}{l}\text { Kawasan Blok Karang anyar, } \\
\text { Rw. } 10 \text { Kelurahan Sumber } \\
\text { Kecamatan Sumber }\end{array}$ & $\begin{array}{l}\text { Peningkatan jalan, pengadaan jamban } \\
\text { keluarga/mck, perbaikan rumah tidak layak } \\
\text { huni, pngadaan air minum/baku pembuatan } \\
\text { dan perbaikan saluran drainase, pengelolaan } \\
\text { sampah }\end{array}$ \\
\hline 3. & $\begin{array}{l}\text { Kawasan Blok Curug, Rw.01 } \\
\text { Desa Situ Kulon Kecamatan } \\
\text { Weru }\end{array}$ & $\begin{array}{l}\text { Perbaikan jalan, pengelolaan sampah, } \\
\text { perbaikan saluran drainase, pengelolaan air } \\
\text { minum/baku. }\end{array}$ \\
\hline 4. & $\begin{array}{l}\text { Kawasan Blok Pondok Bata, } \\
\text { Rw. 05 Desa Semplo } \\
\text { Kecamatan Palimanan }\end{array}$ & $\begin{array}{l}\text { Peningkatan jalan, pembangunan saluran } \\
\text { drainase, pengelolaan sampah }\end{array}$ \\
\hline 5. & $\begin{array}{l}\text { Kawasan Blok } 1, \mathrm{Rw} 02 \text { Desa } \\
\text { Junjang Kecamatan } \\
\text { Arjawinangun }\end{array}$ & $\begin{array}{l}\text { Pengadaan jamban keluarga/MCK, Perbaikan } \\
\text { saluran drainase, perbaikan rumah tidak layak } \\
\text { huni, pengadaan air minum/baku, pembuatan } \\
\text { dan perbaikan saluran drainase, Pengelolaan } \\
\text { sampah. }\end{array}$ \\
\hline 6. & $\begin{array}{l}\text { Kawasan Dusun Pahing-wage, } \\
\text { Rw 02, } 04 \text { dan } 05 \text { Desa } \\
\text { Jatiseeng Kecamatan Ciledug }\end{array}$ & $\begin{array}{l}\text { Perbaikan dan pembangunan saluran drainase, } \\
\text { pengadaan jamban kluarga/MCK, Paengelolaan } \\
\text { sampah. }\end{array}$ \\
\hline 7. & $\begin{array}{l}\text { Kawasan Blok Soka Lor, Rw } 02 \\
\text { Desa Danamulya Kecamatan } \\
\text { Plimbon }\end{array}$ & $\begin{array}{l}\text { Perbaikan dan peningkatan jalan, penadaan } \\
\text { jamban/mck, perbaikan rumah tidak layak } \\
\text { huni, pengelolaan sampah. }\end{array}$ \\
\hline 8. & $\begin{array}{l}\text { Kawasan Rw 02, Rw.02 Desa } \\
\text { Astana Kecamatan Gunung } \\
\text { Jati }\end{array}$ & $\begin{array}{l}\text { Pengadaan air minum, pengelolaan sampah, } \\
\text { pengadaan jamban keluarga/MCK, perbaikan } \\
\text { jalan rusak }\end{array}$ \\
\hline 9. & $\begin{array}{l}\text { Kawasan Dusun, Rw 02, } 03 \\
\text { dan 04 Desa Ambulu Manis- } \\
\text { Pahing Kecamatan Losari }\end{array}$ & $\begin{array}{l}\text { Peningkatan dan perbaikan jalan, } \\
\text { pembangunan saluran drainase, pengadaan air } \\
\text { minum/baku, pengelolaan sampah, perbaikan } \\
\text { rumah tidak layak huni, pengaduan jamban } \\
\text { keluarga atau MCK }\end{array}$ \\
\hline 10 & $\begin{array}{l}\text { Kawasan Rw 03-04, Rw } 03 \text { dan } \\
\text { 04 Desa Kanci Kulon } \\
\text { Kecamatan Astanajapura }\end{array}$ & $\begin{array}{l}\text { Peningkatan jalan, prbaikan jalan rusak, } \\
\text { pembangunan salura drainase, pengelolaan } \\
\text { sampah. }\end{array}$ \\
\hline 11 & $\begin{array}{l}\text { Kawasan Blok D , Rw } 05 \text { dan } \\
\text { 06 Desa Belawa dan } \\
\text { Kecamatan Lemahabang }\end{array}$ & $\begin{array}{l}\text { Perbaikan jalan lingkungan yang rusak } \\
\text { pembuatan saluran drainase, dan pengelolaan } \\
\text { sampah. }\end{array}$ \\
\hline
\end{tabular}

Dari tabel diatas dapat diketahui permasalahan permukiman kumuh disetiap kawasan permukiman memiliki prtiotitasnya masing-masing, masalah permukiman kumuh menyangkut banyak aspek kehidupan masyarakat. Program pengentasan kawasan permukiman kumuh prioritas merupakan 
program pengentasan kawasan permukiman kumuh untuk Kabupaten Cirebon yang dirinci sesuai dengan permasalahan, kebutuhan penanganan kawasan yang lebih detil, serta konsep penanganan kawasan permukiman kumuh prioritas. Program penanganan kawasan permukiman kumuh prioritas meliputi aspek fisik dan aspek non fisik, hal ini mengingat penanganan kawasan permukiman kumuh tidak hanya dilakukan dengan pendekatan fisik, tapi juga dengan pendekatan non fisik. Adapun program fisik yang diusulkan meliputi pengembangan perumahan, jaringan jalan lingkungan, jaringan drainase, jaringan air minum, persampahan, dan air limbah, serta lainnya. Sedangkan dalam aspek non fisik meliputi pemberdayaan masyarakat di kawasan permukiman kumuh. Program penanganan kawasan permukiman kumuh prioritas meliputi aspek fisik dan aspek non fisik, hal ini mengingat penanganan kawasan permukiman kumuh tidak hanya dilakukan dengan pendekatan fisik, tapi juga dengan pendekatan non fisik. Adapun program fisik yang diusulkan meliputi pengembangan perumahan, jaringan jalan lingkungan, jaringan drainase, jaringan air minum, persampahan, dan air limbah, serta lainnya. Sedangkan dalam aspek non fisik meliputi pemberdayaan masyarakat di kawasan permukiman kumuh.

Upaya Pencegahan dan Peningkatan kualitas lingkungan kawasan kumuh dimaksudkan untuk menuntaskan permasalahan kumuh kawasan sehingga apabila setelah dilaksanakan upaya-upaya peningkatan infrastruktur kawasan tersebut, maka predikat kawasan kumuh akan lebih ringan lagi atau malah menjadi kawasan yang tidak kumuh lagi. Untuk mewujudkan penangan permukiman kumuh untuk menghasilkan sebuah permukiman dan lingkungan yang baik, yang diperlukan bukan hanya program atau kebijakan dari Pemerintah saja, namun yang sangat diperlukan adalah kepedulian masyarakat yang cerdas dalam menjaga kesehatan lingkungan permukiman masing-masing. Kreativitas, kebersihan dan kepedulian masyarakat menjadi faktor utama dalam mewujudkan kesehatan lingkungan permukiman yang bersih dan nyaman. Mengatasi masalah permukiman kumuh sebenarnya lebih mudah, swadaya masyarakat dengan hubungan komunitas yang sangat erat akan membentuk suatu situasi warga yang mampu menciptakan permukiman dan lingkungan yang selaras, serasi dan seimbang dengan tata kelola yang baik sehingga akan meningkatkan kualitas kehidupan masyarakatnya.

\subsection{Peningkatan Kemampuan Sosial Masyarakat dalam Menangani Permukiman Kumuh}

Dalam penelitian ini Peningkatan kemampuan sosial masyarakt dapat diartikan sebagai proses partisipasi dan pemberdayaan yang diberikan dalam melakukan suatu porgam atau kebijakan yang berhubungan dengan kehidupan sosial masyarakat itu sendiri. Seperti dalam program pengentasan permukiman kumuh yang ada di Kabupaten Cirebon, progam yang dijalankan adalah program KOTAKU. Program KOTAKU mendukung Pemerintah Daerah sebagai pelaku utama penanganan permukiman kumuh dalam mewujudkan permukiman layak huni diantaranya melalui revitalisasi peran Badan Keswadayaan Masyarakat (BKM). Kontribusi masyarakat melalui pemberdayaan di BKM menjadi kunci suksesnya program KOTAKU. Berdasarkan penjelasan dari Koordinator program KOTAKU Bambang Wijanarko, Program pengentasan pemrukiman kumuh KOTAKU di Kabupaten Cirebon berlandaskan pada 
kolaborasi dan pemberdayaan masyarakat di lingkungan permukiman kumuh. oleh karena itu peningkatan kemampuan sosial masyarakat sangat diperlukan agar tujuan pemberdayaan dari program KOTAKU bisa tercapai. Faktor-faktor yang mempengaruhi Peningkatan kemampuan sosial masyarakat dalam pengentasan masalah permukiman kumuh meliputi pemberian komitmen masyarakat, terlibat aktif dalam pengambilan keputusan, perencanaan, implementasi, pemeliharaan, pengawasan dan kontribusi peningkatan kualitas sosial ekonomi pada penataan kawasan kumuh prioritas (Heston \& Yusuf A, 2013).

Pemberdayaan masyarakat adalah proses pembangunan dimana masyarakat berinisiatif untuk memulai proses kegiatan sosial unutk memperbaiki situasi dan kondisi diri sendiri dengan tujuan agar mereka masyarakat dapat mandiri. Pemberdayaan masyarakat hanya bisa terjadi apabila warganya ikut berpartisipasi. Sejalan dengan itu, pemberdayaan dapat diartikan sebagai upaya peningkatan kemampuan masyarakat (msikin) untuk berpartisipasi, bernegoisasi, mempengaruhi dan mengendalikan kelembagaan masyarakatnya secara bertanggung-gugat (accountable) demi perbaikan kehidupannya (Almas, 2017).

Hasil penelitian menunjukan bahwa kemampuan masyarakat dalam keikutsertaan masyarakat di Program KOTAKU Kabupaten Cirebon memiliki bermacam-macam bentuk, Seperti yang dijelaskan oleh Koordinator program KOTAKU Bambang Wijanarko, di Kabupaten Cirebon terdapat 195 Desa yang termasuk kedalam kawasan permukiman kumuh, jadi kategori partisipasi masyarakat di setiap daerah permukiman kumuh memiliki perbedaan. Di dalam pelaksaan program KOTAKU partisipasi masyarakat ada yang pro aktif, sedang, biasa saja dan ada juga yang sama sekali tidak memberikan partisipasi. Akan tetapi mayoritas pasrtisipasi masyarakat secara keseluruhan termasuk kedalam kategori sedang.

Lebih lanjut Bambang Wijanarko menjelaskan partisipasi yang dilakukan masyarakat dalam program pengentasan permukiman kumuh berupa keikutsertaan dalam program pembangunan infrastrukutur ada dua bentuk antara lain yang memberikan sumbangsi dana secara sukarela dan yang memberikan sumbangsi tenaga dengan menjadi pekerja di pembangunan tersebut.

Sementara itu, terdapat perbedaan pandangan mengenai partisipasi masyarakat yang dikemukakan oleh Ketua Komisi III DPRD Kabupaten Cirebon $\mathrm{H}$. Hermanto mengatakan bahwa pertisipasi masyarakat masih kurang, dilihat dari fasilitas-fasilitas hasil dari pembangunan program KOTAKU tidak terawat dan bahkan sudah ada yang tidak berfungsi dengan optimal. Seharusnya masyarakat lebih mampu dan lebih peduli dengan fasilitas yang sudah dibangun. Tidak hanya mengandalkan bantuan dari pemerintah, melakukan pengembangan dan inovasi sangat diperlukan agar lingkungan permukiman menjadi lebih baik.

Dari penjelasan diatas dapat diartikan bahwa kemampuan masyarakat dalam keikutsertaan program pengentasan permukiman kumuh masih kurang. Partisipasi yang dilakukan oleh masyarakat hanya sebatas pada saat program tersebut berjalan, setelah ada hasil dari pembangunan yang sudah dilakukan perhatian dan kepedulian masyarakat masih sangat kurang sehingga 
mengakibatkan fasilitas-faslitas yang sudah dibangun menjadi tidak terawat dan tidak berfungsi secara optimal.

Untuk mengatasi masalah tersebut sangat diperlukan untuk meningkatkan peran masyarakat dalam proses implementasi, pemeliharaan, pengawasan dan kontribusi peningkatan kualitas sosial ekonomi pada penataan kawasan kumuh prioritas melalui Badan Keswadayaan Masyarakat (BKM) sesuai dengan apa yang ada didalam program KOTAKU. BKM berperan penting untuk peningkatan kemampuan sosial masyarakat dalam permasalahan permukiman kumuh.

\subsection{Komitmen Politik Kepala Daerah dalam menangani Permukiman Kumuh}

Pada pembahasan peneliti menggunakan konsep Political Will dari Brinkerhoff (2010) yang memili lima dimensi yaitu, inisiatif pemerintah, prioritas, mobilisasi dukungan politik, penegakan hukum dan keberlanjutan usaha baik (dalam Achmad et al., 2012 : 4). Melalui program KOTAKU yang sudah berjalan dari tahun 2017 di Kabupaten Cirebon. Tercapai tidaknya tujuan sebuah program tentu saja sangat bergantung pada komitmen politik dari Pemerintah di bawah pimpinan Drs. H. Imron Rosyadi, M.Ag selaku Bupati Kabupaten Cirebon. Berikut ini peneliti jabarkan bagaimana Komitmen politik atau Political will Pemerintah Kabupaten Cirebon dalam menangani permukiman kumuh.

\section{Inisiatif Pemerintah}

Inisiatif berarti adanya suatu tindakan yang berasal dari diri sendiri tanpa adanya paksaan dari pihak tertentu. Inisaiatif dibutuhkan untuk melakukan suatu tindakan yang dianggap perlu demi kebaikan bersama Pada dimensi inisiatif ini yang dinilai mulai dari niat atau inisiatif sampai pada tindakan Bupati Kabupaten Cirebon dalam mengusungkan permasalahan Permukiman kumuh pada masa pencalonan kepala daerah tahun 2018-2023.

Berdasarkan realcount KPU di Pilkada Kabupaten Cirebon Pasangan Sunjaya-Imron memperoleh 32,64 persen suara. Disusul pasangan Kalinga dan Dian Hernawa Susanty memperoleh 26,57 persen, pasangan Mochammad Luthfi dan Nurul Qomar 26,04 persen, serta Rakmat dan Yayat Ruhyat 15,35 persen. Selama masa kampanye visi misi pasangan Bupati terpilih tidak spesifik membahas tentang permukiman kumuh akan tetapi didalam janji-jani politik yang mereka bawa ada beberapa program kerja yang termasuk kedalam indikator-indikator kumuh.

Visi yang dibawa oleh Bupati terpilih Kabupaten Cirebon yaitu "Terwujudnya Kabupaten Cirebon Berbudaya, Sejahtera, Agamis, Maju dan Aman" dan terdapat janji-janji politik yang termuat kedalam 5 Misi antara lain:

1. Kabupaten Cirebon BERBUDAYA : Mewujudkan masyarakat Kabupaten Cirebon yang menjunjung tinggi dan melestarikan nilai-nilai budaya, tradisi dan adat istiadat.

2. Kabupaten Cirebon SEJAHTERA

Meningkatnya kualitas hidup masyarakat melalui pemenuhan kebutuhan dasar masyarakat, peningkatan kualitas pendidikan dan pelatihan, kesehatan dan ekonomi.

3. Kabupaten Cirebon AGAMIS : 
Meningkatnya kualitas kehidupan masyarakat Kabupaten Cirebon yang senantiasa menerapkan nilai agama, budi pekerti, santun dan beretika.

4. Kabupaten Cirebon Maju :

Meningkatnya produktivitas masyarakat untuk lebih maju dan unggul sehingga menambah daya saing di pasar internasional, nasional dan regional, yang didukung oleh peningkatan kapsitas aparatur pemerintah daerah.

5. Kabupaten Cirebon AMAN :

Memelihara keamanan dan ketertiban umum untuk mewujudkan kondusivitas daerah guna mendukung terciptanya stabilitas nasional.

Salah satu janji politik yang terkait dengan masalah permukiman kumuh adalah misi ke 4 yaitu Kabupaten Cirebon MAJU. Didalam misi ke 4 terdapat program yang berkaitan dengan beberapa indikator permukiman kumuh, program-program tersbut antara lain :

a. Peningkatan dan pemeliharaan jalan, jembatan dan irigasi:

b. Peningkatan Infrastruktur daerah perbatasan;

c. Peningkatan pengentasan sampah dan limbah secara terpadu;

d. Pengembangan infrastruktur pendukung dan penguatan kelembagaan untuk mendukung pengembangan agrobisnis

e. Peningkatan ketersediaan lahan perumahan rakyat dan ruang terbuka hijau;

f. Penguatan kebijakan yang mendorong pemenuhan kebutuhan masyarakat melalui penyediaan infrastruktur yang memadai.

Dilihat dari program-program yang direncanakan oleh Bupati Kabupaten Cirebon memiliki Inisiaitif dalam menanggulangi permukiman kumuh, walaupun tidak secara umum langsung menyebutkan tentang permukiman kumuh akan tetapi dalam program tersebut semuanya termasuk kedalam indikator permukiman kumuh.

\section{Prioritas Pemerintah dalam Pengentasan Permukiman Kumuh}

Prioritas menurut KBBI adalah sesutau yang didahulukan atau diutamakan dari pada yang lain. Maksudnya adalah menjadi prioritaskah suatu program atau kebijakan di suatu daerah dilihat dari seberapa besar anggaran yang di alokasikan kemudian seberapa banyak kegiatan yang lain yang berkaitan dengan pencegahan masalah permukiman kumuh. Apabila semuanya masih minim maka program atau kebijakan tersebut bukan menjadi prioritas karena Inisiatif saja tidak cukup harus harus di barengi dengan implementasi dari inisiatif tersebut dengan baik. Jita sudah ada Inisiatif maka perlu adanya tindakan lebih lanjut untuk mewujudkan inisiatif tersebut agar berjalan sesuai dengan yang diinginkan yaitu dengan dijadikannya Inisiatif yang ada sebagai Prioritas.

Di Kabupaten Cirebon ada 195 Desa yang termasuk kedalam kumuh dan 125 Desa dalam kategori pencegahan serta ada 10 Desa yang menjadi kategori peningkatan. Di dalam SK Bupati Cirebon tentang penetapan lokasi perumahan dan permukiman kumuh tahun 2014 terdapat 10 desa yang merupakan kawasan prioritas Pemerintah Daerah Kabupaten Cirebon yang masuk kedalam kriteria Program Kota Tanpa Kawasan Kumuh (KOTAKU). Kawasan permukiman kumuh yang masuk dalam kategori peningkatan secara keseluruhan luasnya 
78,78 Hektar yang tersebar di 11 kawasan dan 10 Desa/Kecamatan. Unutk kawasan yang memiliki tingkat kekumuhannya paling tinggi berada di Desa Ambulu Kecamatan Losari yang juga merupakan kawasan prioritas permukiman kumuh. Setiap kawasan memiliki karakteristik masalah permukiman kumuh yang menjadi prioritas untuk dibenahi menurut 7 Indikator permukiman kumuh. Implemntasi dari program tersebut pada tahun 2018, kawasan permukiman kumuh berkurang seluas 57,13 Hektar dan pada tahun 2019 berkurang seluas 11,58 Hektar akan tetapi di Kabupaten Cirebon masih menyisahkan 10,19 Hektar yang berada di Desa Ambulu dan Desa Setu Kulon.

Di Kabupaten Cirebon untuk pengentasan masalah permukiman kumuh melalui program KOTAKU dianggarkan oleh Pemerintah Pusat, dan untuk kawasan yang tidak mendapatkan bantuan dari program KOTAKU anggaran berasal dari APBD Kabupaten Cirebon, kawasan yang mendapatkan anggaran dana kolaborasi dari Pemerintah Daerah berjumlah 3 kawasan yang yaitu Sumber, Junjang dan Setu Kulon. Peningkatan jalan, pengadaan jamban keluarga/mck, perbaikan rumah tidak layak huni, pngadaan air minum/baku pembuatan dan perbaikan saluran drainase, pengelolaan sampah.

Berikut ini merupakan data anggaran Program KOTAKU di Kabupaten Cirebon berdasarkan Keputusan Menteri Pekerjaan Umum dan Perumahan Rakyat tentang Penetapan Lokasi dan Besaran Bantuan Kegiatan Infrastruktur Berbasis Masyarakat Tahun Anggaran 2018 :

Tabel 4.6 Daftar Lokasi dan Anggaran BPM tahun 2018

\begin{tabular}{lllll}
$\begin{array}{c}\text { KABUPATEN/ } \\
\text { KOTA }\end{array}$ & KECAMATAN & No & DESA/KELURAHAN & $\begin{array}{c}\text { ALOKASI } \\
\text { BDI } \\
(\mathbf{x R p . ~ 1 0 0 0 )}\end{array}$ \\
\hline CIREBON & CILEDUG & 1. & JATISEENG & 1.000 .000 \\
\hline & LOSARI & 2. & AMBULU & 2.000 .000 \\
\hline & LEMAHABANG & 3. & BELAWA & 1.500 .000 \\
\hline & ASTANAJAPURA & 4. & KANCI KULON & 1.000 .000 \\
\hline & SUMBER & 5. & SUMBER & 500.000 \\
\hline & PALIMANAN & 6. & SEMPLO & 1.000 .000 \\
\hline & PLUMBON & 7. & DANAMULYA & 1.000 .000 \\
\hline & WERU & 8. & SETUKULON & 1.000 .000 \\
\hline & GUNUNGJATI & 9. & ASTANA & 1.000 .000 \\
\hline & ARJAWINANGUN & 10. & JUNJANG & 1.000 .000 \\
\hline $\begin{array}{l}\text { CIREBON } \\
\text { TOTAL }\end{array}$ & & & & $\mathbf{1 0 . 5 0 0 . 0 0 0}$ \\
\hline
\end{tabular}

Sumber : Keputusan Menteri Pekerjaan Umum dan Perumahan Rakyat tentang Penetapan Lokasi dan Besaran Bantuan Kegiatan Infrastruktur Berbasis Masyarakat Tahun Anggaran 2018

Secara keseluruhan anggaran yang dialokasikan untuk program KOTAKU berasal dari pemerintah pusat, Pemerintah Kabupaten Cirebon hanya menganggarkan untuk daerah permukiman kumuh yang tidak masuk ke dalam SK Bupati yaitu daerah Sumber, Junjang dan Setu Kulon. Dalam pelaksanan program tersebut masih menyisahkan beberapa kawasan kumuh, hal tersebut disebabkan salah satunya karena anggaran yang terbatas. Berdasarkan penjelasan dari Ketua Komisi III DPRD Kabupaten Cirebon H. Hermanto, dalam program pengentasan permukima kumuh ada beberapa kendala seperti 
anggaran yang terbatas, dikarenakan permukiman kumuh memiliki masalah yang kompleks sehingga anggaran terbagi kedalam semua komponen indikator kumuh, setiap kmponen indikator kumuh harus mendapatkan bantuan, karena hal tersebut program pengentasan permukiman kumuh tidak bisa diselesaikan dengan 1 tahun anggaran. untuk menangani masalah permukiman kumuh pemerintah daerah dalam anggarannya harus lebih optimal, karena banyak variabelnya yang harus ditangani didalam masalah permukiman kumuh.

Dalam aspek prioritas untuk mewujudkan visi misi dan janji-janji politik Bupati dan Wakil Bupati yang didalamnya terdapat program-program prioritas yang berkaitan dengan pengentasan permukiman kumuh dan implementasinya yang sudah sesuai. Akan tetapi dalam hal anggaran masih belum optimal karena anggaran yang disediakan oleh pemerintah pusat masih belum cukup untuk menyelesaikan keseluruhan masalah kawasan permukiman kumuh. dengan demikian komitmen politik atau Political will Pemerintah Kabupaten Cirebon dalam menanggulangi permukiman kumuh dalam aspek prioritas masih belum optimal.

\section{Keberlanjutan Usaha}

Aspek keberlanjutan usaha menjelaskan sejauh mana implementasi dari inisiatif dan niat dari Pemerintah Kabupaten Cirebon dalam menanggulangi permukiman kumuh. niat dan inisiaitif dari Bupati dan Wakil Bupati sudah tercantum dalam Visi Misi dan RPJMD Kabupaten Cirebon tahun 2018-2023, artinya bahwa kebijakan atau program-program yang berkaitan dengan pengentasan permukiman kumuh masih berlanjut dan berlaku sampai masa pemerintahannya berakhir. Dalam rencana strategis Dinas Perumahan, Kawasan Permukiman dan Pertanahan terdapat beberapa masalah yang terjadi dalam pengentasan kawasan permukiman kumuh, diantaranya adalah Masih minimnya data base mengenai perumahan dan kawasan Permukiman, Belum jelasnya arah kebijakan pengembangan kawasan permukiman Kab. Cirebon, dan Belum teridentifikasinya kawasan kumuh perkotaan secara menyeluruh, dan pengentasan kawasan kumuh berdasarkan SK Kumuh Bupati masih belum tertangani.

Pengentasan kawasan pemukiman kumuh Kabupaten Cirebon ditahun 2019 masih belum selesai dan menyisahkan kawasan kumuh. Program KOTAKU tidak berhenti ditahun 2019 dan masih berlanjut di taun 2020 sampai dengan tahun 2024. Ada beberapa kawasan permukiman yang mendapatkan program lanjutan Livelihoods, program tersebut bertujuan dalam pembangunan sosial masyarakat, karena di kawasan permukiman kumuh tidak hanya infrastrukturnya saja yang harus dibenahi, akan tetapi kehidupan masyarakatnya juga harus dibenahi seperti mata pencaharian agar mereka bisa hidup dengan layak dan terhindar dari kemiskinan. Livelihoods adalah sebuah strategi keberlanjutan untuk mengatasi permasalahan dari tekanan dan gangguan atau meningkatkan kapasitas dan aset. Keseluruhan aset Livelihoods dipengaruhi oleh adanya kerentanan yang terjadi dalam permukiman kumuh, yaitu budaya, pendidikan, konflik, kebencanaan, kesehatan, dan income, juga keuntungan kompetitif dari lokasi permukiman seperi nilai strategis kawasan, peluang usaha, potensi kemitraan, dan kearifan lokal. Pneguatan kerentanan yang terjadu akan memberikan dampak pada fungsi rekayasa sosial-ekonomi dari lingkungan permukiman kumuh dan rekayasa fisik-lingkungan. Faktor 
yang memengaruhi keinginan masyarakat dalam melaksanakn konsep Livelihoods antara lain : Kerentanan, kebijakan-kebijakan, proses, dan kelembagaan (Prayitno, 2007).

Program lanjutan Livelihoods di Kabupaten Cirebon terdapat di Desa Belawa yang nanti akan di bangun Rumah Olahan mangga dan kemudian menjadi kawasan Ekowisata. Berdasarkan penjelasan dari Kepala Desa Belawa Kamon Haryanto, Program Kotaku sudah berjalan lima tahun, dari tahun 20152019 di Desa Belawa sudah mencapai target, Desa Belawa mendapatkan program lanjutan sampai tahun 2024. Program lanjutan tersebut berbentuk program Livelihoods yang nantinya dibangun rumah olahan mangga di kawasan objek wisata Cikuya dan kawasan kebun mangga, rumah olahan mangga akan di jadikan kawasan ekowisata yang diharapkan akan menjadi mata pencaharian masyarakat Desa Belawa dan mensejahterakaan masyarakat.

Dapat disimpulkan dalam aspek keberlanjutan usaha dari kebijakan pengentasan permukiman kumuh di Kabupaten Cirebon Dikategorikan cukup baik dengan beberapa catatan yang perlu diperbaiki. Dapat dilihat program tersebut masih berlanjut sampai akhir periode karena sudah tercatat dalam RPJMD Kabupaten Cirebon tahun 2018-2023. Program KOTAKU yang sudah berjalan selama lima tahun di Kabupaten Cirebon masih terus berlanjut dan bahkan sudah ada program turunannya yaitu program livelihoods yang bertujuan untuk memberdayakan masyarakat di daerah permukiman kumuh.

\section{PENUTUP}

Berdasarkan pemaparan diatas peneliti menyimpulkan beberapa hal mengenai peningkatan kemampuan sosial dan komitmen politik. Peningkatan kemampuan sosial Masyarakat di kawasan permukiman kumuh Kabupaten Cirebon dapat disimpulkan dari faktor komitmen masyarakat terlibat aktif dalam pengambilan keputusan, perencanaan, implementasi, pemeliharaan, pengawasan dan kontribusi peningkatan kualitas sosial ekonomi pada penataan kawasan kumuh prioritas masih belum optimal, pasrtisipasi dan pemberdayaan masyarakat hanya sebatas pada saat program KOTAKU berlangsung, setelah program selesai masyarakat kurang aktif dalam memelihara fasilitas-faslitas yang sudah dibangun.

Untuk komitmen Bupati dan Pemerintah Kabupaten Cirebon dalam menangani permukiman kumuh secara keseluruhan sudah cukup baik, antara lain: Inisiatif pemerintah dalam menangani permukiman kumuh melalui program yang sudah direncakan, walaupun tidak secara umum langsung menyebutkan tentang permukiman kumuh akan tetapi dalam program tersebut semuanya termasuk kedalam indikator permukiman kumuh. Kemudian dalam aspek prioritas dapat disimpulkan bahwa, komitmen politik atau Political will Pemerintah Kabupaten Cirebon dalam menanggulangi permukiman kumuh dalam aspek prioritas masih belum optimal dikarenakan oleh anggaran masih belum optimal karena anggaran yang disediakan oleh pemerintah pusat masih belum cukup untuk menyelesaikan keseluruhan masalah kawasan permukiman kumuh di Kabupaten Cirebon. Sedangkan untuk aspek keberlanjutan usaha dari kebijakan pengentasan permukiman kumuh di Kabupaten Cirebon dikategorikan cukup baik dengan beberapa catatan yang perlu diperbaiki. Dibuktikan dengan program pengentasan permukiman kumuh masih berlanjut sampai akhir periode Bupati Kabupaten Cirebon pada tahun 2023, serta 
program KOTAKU yang sudah berjalan selama 5 tahun di Kabupaten Cirebon masih terus berlanjut dan bahkan sudah ada program turunannya yaitu program livelihoods yang bertujuan untuk memberdayakan masyarakat di daerah permukiman kumuh.

Berdasarkan kesimpulan yang diperoleh dari hasil penelitian diatas maka peneliti memberikan beberapa saran yang dapat dijadikan masukan bagi pihakpihak yang terlibat dalam pengentasan permukiman kumuh, yaitu:

1. Dalam meningkatkan pasrtisipasi dan pemberdayaan masyarakat peneliti menyarankan untuk memaksimalkan peran Badan Keswadayaan Masyarakat dan juga meningkatkan kepedulian dan kesadaran masyarakat terhadap lingkungan sekitar beserta fasilitas yang sudah dibangun.

2. Dalam komitmen Politik Bupati Kabupaten Cirebon ada beberapa saran yang buat oleh penulis, antara lain :

a. Dalam aspek komitmen politik menurut dimensi inisiatif, saran dari peneliti yaitu Pemerintah Kabupaten Cirebon harus mengimplementasikan Inisiatif yang sudah ada didalam visi misi dan RPJMD Kabupaten Cirebon dan tidak hanya bergantung pada Porgram KOTAKU. Merencanakan dan membuat inovasi program yang berlandasakan pemberdayaan masyarakat untuk kawasan kumuh yang tidak tertangani oleh Program KOTAKU.

b. Dalam aspek prioritas saran dari peneliti yaitu dijadikannya masalah kawasan permukiman kumuh sebagai prioritas Pemerintah dan segera disahkannya Rancangan Peraturan Daerah tentang kawasan kumuh agar pada saat perencanaan dan pembuatan program anggaran dari Pemerintah Daerah bisa lebih besar untuk dialokasikan dan jelas ada peraturan yang menjadi landasan hukumnya.

c. saran dari peneliti yaitu Pemerintah harus mendata kawasan permukiman kumuh yang tidak masuk kedalam data Kawasan Kumuh karena dalam RENSTRA DPKPP masih banyak kawasan yang belum terdata, kemudian Pemerintah Kabupaten Cirebon membuat perencanaan program dan kegiatan yang berkaitan dengan Pencegahan dan penanggulangan permukiman kumuh di daerah yang belum terdata.

\section{DAFTAR PUSTAKA}

Achmad, A. F., Library, S., Faculty, G., Science, S., Campus, R., Widya, B., Km, S., Pekanbaru, N., \& Fax, P. (2012). POLITICAL WILL PEMERINTAH KABUPATEN PELALAWAN TERHADAP PELESTARIAN SATWA DI TAMAN NASIONAL TESSO NILO TAHUN 2011-2012 Tesso Nilo merupakan hutan hujan dataran rendah yang tersisa di Pulau Sumatera. Fungsinya yaitu menjaga keseimbangan ekosistem berbagai . 2(2).

Brinkerhoff, D. (2010) Unpacking the Concept of Political Will.

Creswell, J. W. (2016). Research Desain Pendekatan Metode Kuaitatif, Kuantitatif, dan Campuran. Yogyakarta: Pustaka Pelajar.

Dinas Perumahan, Kawasan Permukiman dan Pertanahan. (2019). Rencana Strategis Dinas Perumahan, Kawasan Permukiman dan Pertanahan

Hartman, C. (1998). The Case for a Right to Housing. Housing Policy Debate, 9(2), 
223-246. https://doi.org/10.1080/10511482.1998.9521292

Heston, Y. P., \& Yusuf A, A. (2013). PENGUATAN KEMAMPUAN SOSIAL PADA PENATAAN KAWASAN KUMUH PERKOTAAN (Studi Kasus Kelurahan

Cigugur Tengah Cimahi). Jurnal Tataloka, 15(3), 208.

https://doi.org/10.14710/tataloka.15.3.208-217

Owusu, G., Agyei-Mensah, S., \& Lund, R. (2008). Slums of hope and slums of despair: Mobility and livelihoods in Nima, Accra. Norsk Geografisk Tidsskrift - Norwegian Journal of Geography, 62(3), 180190. doi:10.1080/00291950802335798

Prayitno, B. (2007). Beyond Titling. 4th Urban Research Symposium.

Sugiono. (2017). Metodologi Penelitian Kuantitatif, Kualitatif, dan R\&D. Bandung:Alfabeta

Sukmadinata, Nana Syaodih. 2009. Metode Penelitian Pendidikan. Bandung: Remaja Rosdakarya

Undang-undang No. 1 Tahun 2011 tentang Perumahan dan Kawasan Permukiman

UN-Habitat. 2006. State of the World's Cities 2006/2007. Nairobi: United Nations Human Settlements Programme.

Un-Habitat. (2007). What are Slums and why do they exist. Sustainable Urbanization: Local Action for Urban Poverty Reduction, Emphasis on Finance and Planning:Twenty First Session of the Governing Council 16 - 20 April 2007, Nairobi, Kenya What, April, 7623151-7623153.

Un Habitat. (2013). State of the World's Cities 2012/2013. State of the World's Cities 2012/2013. https:/ / doi.org/10.4324/9780203756171

Un Habitat. (2013). State of the World's Cities 2012/2013. State of the World's Cities 2012/2013. https:/ / doi.org/10.4324/9780203756171

Yusuf A. (2013). PENGUATAN KEMAMPUAN SOSIAL PADA PENATAAN KAWASAN KUMUH PERKOTAAN (Studi Kasus Kelurahan Cigugur Tengah Cimahi). Jurnal Tata Kelola., ISSN: 0852-7458 DOI: 10.14710/tataloka.15.3.208-217 